\title{
ONTOLOGICAL DRAWINGS: A COLLABORATIVE METHOD FOR RESEARCH WITH AMERINDIAN SOCIETIES
}

YACOPO CACELA BRIZZI ${ }^{1}$

ISCTE-IUL / NOVA-FCSH, PORTUGAL

https://orcid.org/0000-0002-9324-9002

\begin{abstract}
RESUMO: O presente artigo explora as dimensões ontológicas do desenho e a sua utilidade como método de pesquisa colaborativa com sociedades amerindias. Com foco em uma revisão bibliográfica da etnologia ameríndia e do desenho como método em Antropologia, procura realçar as especificidades do desenho como processo e produto para diferentes contextos amazônicos, chamando a atenção para os diversos "equívocos descontrolados" que devem ser levados em consideração. O escrutínio da composição dos desenhos através das suas formas, cores, materiais e respectivas capacidades de agência definidas por diferentes grupos ameríndios, colocam estes tipos de desenho em uma categoria especial que pode auxiliar pesquisadores a compreender mundos desconhecidos e expandir o interesse no uso do desenho como um método de pesquisa em Antropologia.
\end{abstract}

PALAVRAS-CHAVE: estética ameríndia, pesquisa colaborativa, desenhos indígenas, grafismo, desenho ontológico

ABSTRACT: The following article explores the ontological dimensions of drawing and its utility as a collaborative research method with Amerindian societies. Focusing on a bibliographic review of Amerindian ethnology and drawing as a method in Anthropology, it attempts to enhance the specificities of drawing as a process and product for different Amazonian contexts while calling attention to the various "uncontrolled equivocations" that need to be taken into consideration. The scrutiny of the composition of drawings through their shapes, colours, materials, and the respective agentive capacities defined by different Amerindian groups place these types of drawing in a special category that may aid researchers in understanding uncharted worlds and expand interest in using drawing as a research method in Anthropology.

KEYWORDS: amerindian aesthetics, indigenous drawings, collaborative research, graphism, ontological drawings

${ }^{1}$ Doutorando em Antropologia pela ISCTE-IUL / Universidade de Nova Lisboa, Portugal. E-mail: ycbia@iscte-iul.pt 


\begin{abstract}
"Speaking, for example. I am now speaking for you. Otherwise, I would surely do so in a different way. I would not develop the concepts in order to fit your understanding. But I'm forced to use your words. I have to fit my words inside yours and adapt my thoughts, silencing others that do not fit, that rebel against that confinement you call coherence. If we had enough time to be worthy, perhaps I might show you how to use my eyes, to speak with my mouth. Maybe you would understand. As it is, I have to reduce everything. The obstacle is time."
\end{abstract}

Maestro Ino Moxo talking to César Calvo (CALVO, 1995)

\title{
Introduction
}

In the most recent decades, anthropological theory and methodologies have been strongly influenced by ideas about agency. What agency is and who or what is capable of producing effects on everyday life has been used to debate the existence of other worlds in which Western precepts of agency and difference are not applicable. How reality comes into being and what makes part of it supported discussions where universal logic and consequent ideas of culture as representation clashed with ideas about the ontological foundations of other worlds along with the legitimacy of the different realities that thus are constituted (BLASER, 2013; CARRITHERS et al., 2010; DESCOLA, 2013; GRAEBER, 2005; HENARE et al., 2007; HOLBRAAD \& PEDERSEN, 2019; KOHN, 2015; VIVEIROS DE CASTRO, 1998). The 1980s and 1990s signal a time of change when philosophy and scientific methods, including Anthropology, were put at most stress. Theoretical approaches and ethnographic practice built over a Euro-American scale of reference were paired with theories based on indigenous knowledge focused on abolishing Western academic hegemony. The conceptual tools that emerged from such discussions influenced the ethnographic work that has been done since, with particular emphasis on Amerindian studies. Significant contributions such as Strathern's (1988) research about the "dividual" and the origin of "relation" in British terminology as a critical concept for Social Anthropology, Wagner's (1975) discussion of convention and innovation, regarding the invention of culture and obviation process among the Daribi, Viveiros de Castro's "Amerindian Perspectivism" (2004), and Descola's (2013) "universal relativism", are some examples of a shift that lead to what came to be known as "the ontological turn" (HENARE et al., 2007). More recently, critics to a model of living associated with how Western based knowledge systems spread and dominate across the world (s) (ESCOBAR, 2018; MIGNOLO, 2010; QUIJANO, 2010), and studies regarding the ontological status of things and persons, of objects and subjects, of the "degrees of animacy" (SANTOS-GRANERO, 2009) present in the compounds of what constitutes reality, enabled an academic movement towards indigenous thinking nowadays more interested in 
revealing other worlds than to inquire about their existence (BLASER, 2013 ; DE LA CADENA, 2010; ESCOBAR, 2018; LAW, 2011). Santos (2007), for example, calls attention to the "abyssal line" that confers legitimacy to the modern world by exhausting and neutralizing other ways of thinking through their invisibility. The argument focuses on how knowledge systems, namely science and law, are producers of a discrete erasure of non-Western modes of thinking and subsequent legitimacy of differently experienced worlds. By establishing the limits of truth and law, modern world-making hides in its dichotomies a perverse monopoly of universal truths. Other experiences, ways of thinking, kinds of agency, of which origin stems from indigenous, layman, peasant, and other nonWestern knowledge systems, characterized beyond the parameters of uncertainty that belong to the Western world, have more than often been made invisible, non-existent and non-important.

In the years that followed the theoretical and methodological crisis in Anthropology about the deception of ethnographic practice and problems related to the authority to represent and systematize cultures (ABU-LUGHOD, 1991, CLIFFORD \& MARCUS, 1986), attention was partially redirected to the use of indigenous methodologies as a breakthrough movement to decolonize knowledge production and validate indigenous knowledge systems (AGRAWAL, 2002; CHILISA, 2013; SMITH, 1999). Furthermore, Indigenous film producers, indigenous photographers, and other expressions produced by Amerindians encouraged emic perspectives while following an evolving worldwide building of indigenous alliances. The project Video Nas Aldeias, as an example, developed initially by Vincent Carelli, promotes the use of video to encourage local communities in the diffusion of their worlds (RODRIGUES, 2019). Focus on such methodological strategies through collaborative projects involving community building has been stimulating self and collective empowerment and contributing to indigenous selfdetermination processes.

Suppressed by colonial domination, Amerindian worlds remained, and remains, hidden to outsiders, both researchers and colonists. One of the reasons why it continues to be difficult to grasp Amazonian worldmaking experience has to do with the quality of the observer and its incapacity to perceive the properties of Amerindian thinking. Based on particular settings that recognize specific characters of perception, agency, for distinct groups, results from differently measured entanglements of subjects and objects, material and immaterial, visible and invisible, human and non-human. The striking difference between thinking through a universal logic and availing one only reality on the one hand, or through the ontological particularities of distinct groups that allow for the existence of other worlds on the other, is rooted in the different ways agency is perceived from different things and situations, as well as on the inclusion of these agencies in networks of sociability that are required for social cohesion. Not understanding that reality is based on ontological assumptions related to individual and group experiences hinders the possibility of communication between different world-making values and processes. The historical clashes that are 
evidence of prejudice and ethnocentrism resulting from cultural communication problems were defined as "uncontrolled equivocations" (VIVEIROS DE CASTRO, 2004), enhancing the fallibility of cultural translation and the impossibility of completely understanding the "other" as well as the constituents of the world that is conceived.

The aesthetic production of Amerindians may be considered a reliable example of the kind of "uncontrolled equivocations" that some researchers have been trying to surpass. Object to previous debates in Anthropology discussing whether it could be a cross-cultural concept and used in comparative studies (INGOLD, 1996), aesthetics, in Amerindian context, was adopted to designate magical and everyday practices of Amerindians that require as a condition "to be in relation with something"*2 indicating alterity relations with the Cosmos and Nature (DAMIÃO \& BRANDÃO, 2019). These manifestations that include drawing, painting, dancing, ritual, and everyday praxis are fundamental for transmitting guiding values for Amerindian groups. Aesthetics has been identified with the capacity of revealing elemental traits of conduct, often assembling the mythic, the now and the future, oniric and trance events, ancestor's knowledge, powerful non-human beings, and other important cosmological and social events. By deviating attention from the symbolic values common to representational perspectives of Western aesthetics to its "efficacy" (LAGROU, 2009), "indigenous arts"" (VAN VELTHEM, 2010) as will be further discussed, report the omnipresence of non-human cosmic constituents along with the moral and ethical guidances that are brought with them (OVERING \& PASSES, 2000). Considered in this article as a particular type of "indigenous arts", Amerindian graphism is defined not only by what is drawn, painted, or sculpted, but also where, how, and what materials are used, with relevant consequences when the researcher proposes paper, pencils and other alien materials and techniques (BARCELOS NETO, 2018; MACK, 2012).

The use of drawing as a method for research with Amerindian peoples requires to understand the historical relations and circumstances in which Euro-American materials and techniques came to be known by Amazonian collectives and how they are being used, acknowledged, or avoided (COLLET, 2013; GOW, 1990; MACK, 2012). The presence of Western materials such as the bible and journals, adding to the consecutive events that determined the suppression of native groups by colonial presence, such as slavery, violence, epidemics, and other colonial domination examples, are reflected on the way indigenous groups may or may not avail and integrate Western-based knowledge systems, and by extension their symbolic material culture. Davi Kopenawa's statements exemplify the kind of apprehension native groups have towards Western ways of producing and transmitting knowledge. For the Yanomami shaman, the "images" on paper (words) do not correspond to proper knowledge and are not capable of depicting the ontological domains of Yanomami cosmology (ALBERT, 1995). Analogically, just as Europeans downgraded indigenous drawings, writing is also eschewed from

\footnotetext{
${ }^{2}$ The author of this article translated all citation identified with *
} 
indigenous perspectives.

The transformational character of Amerindian ontologies demonstrates that the fabrication of personhood through the incorporation of exogenous elements allows for the acquisition of perspective as a centre of agency. Matters related to alterity are particularly pertinent because in the same way that the extension of humanity to non-human beings acknowledges its point of view, its consumption (predation) produces the subject while temporarily adopting the other's perspective (VIVEIROS DE CASTRO, 2014). There are, however, other ways of seeing and being seen as "other" besides "predation" or shamanism, and aesthetics play the fundamental role of allowing to change surfaces and "becoming", both for humans and non-humans. Materials and techniques used to crystallize Amerindian worlds reveal the relational dimension of knowledge and social praxis by means of acknowledging subjects through its agentive capacity. The amount of power that is conceded to different agents, often non-humans, in many instances forces their manifestation through metonymic reference and by means of indexation through aesthetics, frequently demanding expertise both to build relations and to decipher them.

Based on a bibliographic review of collaborative works done between researchers and Amerindians, the article will exemplify what kind of information may be retrieved through drawing. As a brief effort to systematize this particular kind of graphism, the ontological drawing as a method represents an attempt to be careful about what people say (draw) (VIVEIROS DE CASTRO, 2004) of themselves and their worlds. In order to circumscribe specific types of drawings as ontological drawings and distinguish them from other visual expressions and Amerindian arts, attention should be given to the ontological traces that are made visible in the process and product of drawing. As will be argued, the composition and process, materials and techniques, are all prone to "uncontrolled equivocations", and all elements need to be taken into consideration and examined carefully. Furthermore, the capacity to perceive agency through "seeing" often corresponds to an assemblage of empirical origin which through its graphic production may become more accessible to researchers, encouraging new ways of exploring indigenous worlds and cosmologies.

Along with inquiring about the process and composition of drawings, researchers need to be careful about their reproduction. In Amerindian context, the concept of image, its copy, as well as other forms of visual representation are often associated with the "capturing" of the soul. Similarly, the knowledge needed to produce "things" may be restricted, untransmittable, directly associated with non-human agents, and thus with the capacity to generate social and cosmological consequences. Finally, the ontological drawing sets on a fine collaborative work between researchers and participants in which the researcher develops attention and awareness to the composition, materials, and process of drawing, while participants are asked to give shape to aspects of their worlds which normally are not expressed through drawing. 


\section{Drawing as a research method}

Voyagers, missionaries, and researchers used drawings to hold visual memory of places and peoples. As a perspective of reality charged with colonial domination, the image construction of "devilish" and "cannibalistic" Indians supported the need of "saving" these people often considered more related to animals than to humans. Mirzoeff (2011) talks about the power of visuality in contexts of colonial domination and why it has been an important factor in establishing hegemony and as a supporter of colonial action.

Though contemporary theories in Anthropology recognize the subjective and ontological dimensions of "making things" for indigenous peoples, including all forms of crafts and expressions, in the $19^{\text {th }}$ century, as one of the first methods used by ethnographers to depict "the other" and its exotic landscapes, indigenous drawings were used to investigate the subject's mentality and personality (SOUKUP, 2014). Inspired by cognitive and psychological interests, experiments based on drawings were conducted to produce comparative studies of cognitive capacity between different cultures (MACK, 2012). The practice continued throughout the 20th century bounding the technique to colonial power and evolutionary theory because writing was considered a superior cultural form and only accessible to civilized and literate people, feeding colonial asymmetries and downgrading indigenous capabilities of expression. The limiting aspects attributed to orality and the absence of writing in Amerindian tradition fostered opinions that focused on the limitations to organize and systematize information, the ability to think critically about tradition, and diminished memory depth. On the other hand, writing was seen as an exclusive tool of civilization and a warrant of "scientific" knowledge with historical depth and reflexive analysis of content (CESARINO, 2012). At the beginning of the 20th century, drawing was replaced by photography as one of the most used methods employed for visual testimony to be only surpassed by the rapid pace of ethnographic documentaries in the 1970s, when also the manifesto for Visual Anthropology was released (SOUKUP, 2014).

Though used tangentially as a method in Anthropology, nonmechanical image production such as drawing allows for time to reflect, adding and completing the image according to one's will. Furthermore, by freely setting the lines and boundaries of the drawing, it returns power to its creator while significantly contributing to research both of what is made visible and for what remains hidden or not depicted (LITERAT, 2013). Participatory drawing was described as a "non-textual way of knowing" that activates the "performative dimensions" of image-making (LITERAT, 2013, apud SINGAL \& RATTINE-FLAHERTY, 2006). The use of illustrations as elicitation has been used as a "mnemonic device" to probe and explore social memories triggering "scattered and fragmented images" (AFONSO, 2004). It has also been used in research with children to break down power relations asymmetries between researchers and participants, as well as on a broader set of situations where verbal communication is difficult or impossible such as research with learning- 
disabled people, migrant communities, or conflict situations where the description of intangible feelings like violence, fear or pain can be facilitated by using drawing as a method (ANTONA, 2019; SØNDERGAARD \& REVENTLOW, 2019).

Despite the use of drawing being effective as a way to materialize feelings, emotions, and other complex situations, reviewing the utility of drawing for Amerindian research through an ontological perspective requires breaking down possible "uncontrolled equivocations" that notwithstanding may lead into a fallible conclusion and be questioned about its colonial legacy as a method (MACK, 2012). Due to the overwhelming amount of research done and increasing available bibliography that is being produced about Amerindian ethnology, the following sections will briefly describe some of the emerging themes on Amerindian arts, to evolve into the visual aspects of Amerindian graphism in order to expose some of the features that may be prone to equivocations.

\section{Amerindian Arts}

The recognizable work done by several authors in the last decades (BARCELOS NETO, 2002; GOW, 1988; LAGROU, 2007; MÜLLER, 2010; VIDAL, 2000; VAN VELTHEM, 2010; RIBEIRO, 1983, among many others) has brought attention to Amerindian ethnology. Importance was given to the knowledge and meaning involved in the process of "making things"

for different Amerindian populations, of techniques such as body painting, basketry, pottery or culinary, and how these productions imply a proper perception of Amerindian cosmology, alterity relations, and ontological features that permeate indigenous life.

"Indigenous arts" (VAN VELTHEM, 2010) is a concept brought to differentiate Amerindian processes and products, and refers to the agentive capacity of form, image, and objects, differing from the arts' formal Western orientations of contemplation, awe or interpretation, and due to the variable range of functions portrayed in each different Amerindian collective, "Indigenous arts" should, agreeing with the author, be referred to in plural. Furthermore, "indigenous arts" are deeply connected with a profound knowledge of the mythic narratives and ritual practices (VAN VELTHEM, 2010), where aesthetics play a determinant role in all moments of sociality (LAGROU, 2007; OVERING, 1996). As previously shown by other authors (GELL, 1998; GOW, 1999; INGOLD, 1996; OVERING, 1996; OVERING \& PASSES, 2002), aesthetics is connected with Kantian philosophy and rationality, as well as with a controlled distinction between techne and ars, as a stronghold of Western metaphysics towards a dominating universalistic logic (CECÍLIA DE OLIVEIRA, 2019). While Alfred Gell (1994) criticizes the historical perspective of art and religion that declared art as a universal truth, and explains why both may be understood as a transcendental function of Western and elitist society, in "Indigenous arts" (VAN VELTHEM, 2010), aesthetics and beauty are related to political and moral values (OVERING, apud BEYSEN, 2013), rather than 
any kind of art-like qualitative validation justifying thus its logic of immanence instead of transcendence (LAGROU \& VAN VELTHEM, 2018). Recent approaches to Amerindian aesthetics are highly influenced by Alfred Gell's "Art and Agency" (1998). The author's contribution with the theory of abduction broadened concepts of agency to objects of art, contouring representative and logical interpretative models of agency. In addition, the Actor-Network-Theory (LATOUR, 2005) further declassified divisions between subjects and objects by considering equally the agentive capacity of both human and non-human constituents of reality.

Following a new perspective on Amerindian ethnology, which broadened concepts of agency to previously uncharted fields, efforts were directed to understand the potential of aesthetics, especially regarding its communicative function and efficacy in understanding the life of nonordinary realities and non-human action. The contemporary ethnological approach is significant for indigenous people's struggles because it empowers Amerindian world making by valuing self-discourses of relational networks and cosmologies. In Amerindian contexts, Paolo Fortis (2012) prefers to define Kuna's intricate visual art as a category of experience and a way of knowing rather than relating it to aesthetics. Indigenous arts were also described as "instruments of perception"* (BELAUNDE, 2013) that allow a passage between perceptive worlds. For Barcelos Neto (2002) art is, in many cases, "agent of itself*", "a meeting between subjects", an "imprisonment" (ibid: 263) where the manifestation of subjectivity disregards the presence of humans, thus denying the idea of representation and art as object.

Though indigenous arts are collectively performed, each production remains an individual experience in which each person is the owner of its production (LAGROU \& VAN VELTHEM, 2018). For this reason, it is considered an individual expression of a collective idea (RIBEIRO, 2000), or as a profound individual experience with the supernatural (BARCELOS NETO, 2002). Common to Amerindian thinking, the artist serves as a mediator between worlds, and its creativity is often associated with a knowledge that was given by mythical beings, stolen from them, or as a description of non-ordinary experiences during trance states or dreams (BARCELOS NETO, 2002; BELAUNDE, 2012; FORTIS, 2012; LAGROU, 2007; LANGDON, 2013). A widely spread concept in Amazonia relates the origin of knowledge with a precise mythical moment when humans came in possession of it. As explained by Belaunde's work (2013) with the ShipiboConibo, Kene designs, a particular kind of abstract pattern familiar also to different other Amerindian groups such as the Huni Kuin (LAGROU, 2007) and the Piro (GOW, 1999), are expressions of Anaconda, the mother of water and water plants, the mighty generator and predator cosmic being who obliges women to draw her patterns so they may be seen. Kene drawings are animated, "have flame*", "accumulated power*", being able to transform and cure the world, making it beautiful. However, while the world becomes beautiful, kene designs are also labyrinths, attracting the knowable spectator inside the graphic space allowing for a change of perspective and possible communication with non-human agencies (BELAUNDE, 2013). 
On some occasions, the knowledge needed to produce "things" is not regarded as transferable beyond well defined circles. GALLOIS (2012) explains how the possibility of setting Kusiwa drawings as community heritage among the Wajapi resulted in a discussion over the real owners of such visual expressions. The problem points to the possible consequences of relaying knowledge that is property of ancestors, specialized shamans, and other actors who belong to a chain of transmission. For the Wajapi, knowledge transmission may cause weakness to those who gave it away or sold it, may be recaptured by its real original master, and become unavailable for the collective. As such, Wajapi elders sustained that the community does not own the Kusiwa patterns. They are, instead, the proof of the existence of non-humans beings, their vital principles and manifestations, and for this reason, it is not possible to declare ownership over them. In the same manner, "imitation" (wa'ã) of patterns by duplication, photographing, filming, drawing, and everything that makes non-humans "visible", is a dangerous activity because they call attention from the owner of such designs, and people are under scrutiny about the correct usage of áãga (images). Among the Wauja, for example, the replication of palatsi (image) is extremely dangerous, being the reason why nobody would draw a family member, and refused pictures to be taken of them or Wauja art because the image is homologous to the soul. Furthermore, the manipulation of drawings and patterns must be made showing respect to the real "owners" Apapaatai and Yerupoho, the non-human entities which pervade Wauja cosmology. The danger that the images may be used in a way that Jarã (non-human entities) dislike may revert through sickness and disease because they allowed its use (BARCELOS NETO, 2002). Laziness and despise in the drawing performance may also result in illness or death to humans (BEYSEN, 2013).

The way knowledge is acquired and passed on seems to agree with "perspectivist" theories in what regards the "making" of personhood as a manifest expression of "predation" (VIVEIROS DE CASTRO, 2014) where the incorporation of the "other" is what cumulatively defines a person. Amerindian arts, in this sense, was associated with a logic of "conquer" (LAGROU, 2007) over unknown worlds, non-humans, neighbours, or enemies, and serves as inspiration and legitimacy (LAGROU, 2009; 2013; SEEGER, 2015), fomenting the exogenous and transformational character of Amazonian people's "fabrication" and modeling. The strong emphasis placed on body transformation (SEEGER et al., 1979), along with a constructionist character of personhood and "becoming", show significant efforts to preserve the integrity of the human point of view through bodymaking and body-shaping as it is "the body that shapes consciousness" (SANTO-GRANERO, 2009: 23), and the preferred space to inscribe difference. By transforming the body, mainly through aesthetic practice, one is acquiring sociability, becoming what is expected by the collective, a processual individual transformed by social praxis and highly motivated by Amerindians arts with the same performative action of body "fabrication" (LAGROU, 2009). In this sense, a body understood as a "bundle of affections" (VIVEIROS DE CASTRO, 2014) may only act if it 
performs or if it is the place of transformation, if it is acknowledged and seen by oneself and the collective.

Indigenous Arts are directly related to the ontological corpus and mythological sphere and represent specific modes of thinking in intricate ways related to cosmological and everyday life events. They are connected to different cosmological orders by "suggesting" the omnipresence of alterity relations, namely the invisible, immaterial, and mythological spheres (BARCELOS NETO, 2002; SEVERI \& LAGROU, 2013). As subjects become independent of their referents and may be understood in different situations and surfaces, or by the possibility of the same "thing" to express several entities and intentions through projection, to act as "chimeric" (SEVERI, 2013) devices, the kind of possible analysis to Amerindian arts transfers its value from symbolic studies which separate nature (symbol) and culture (representation) to a "symbolic experience" which is "raised by some expressive entity or form that refers to an absence, distance or separation"* (Cesarino, 2012: 115).

Important for the aesthetic debate, the concept of beauty in social sciences was discussed by Bordieu in his 1979's book "Distinction" (1984). The author argues that matters of "taste" and "beauty" are constructs that prove social power imbalances among the society eminently connected with social strata of Western culture. For Amerindians, differently, it was more accurately related to its "efficacy" (LAGROU, 2005), mobilizing a semiotic and agentive capacity that allows paintings and objects to express and act over reality. To become "beautiful" for Amerindians is to be acknowledged by the spirits as an interlocutor for the production and reproduction of knowledge and intimately associated with moral and political values of what is "good". According to Joanna Overing (1996) "beautification plays a part, first and foremost, in a process of everyday empowerment that enables both a person and an object to act productively" (ibid: 212-213). Among the Huni Kuin, for example, during the passage rites, the most appreciated facial paintings are executed "badly", by imprinting thick and imprecise lines on the body with the fingers, contrasting with the fine paintings done on other occasions by adults. The neophyte's "liminal" clothes allow the body to be imbued with protection against spirits (LAGROU, 2007).

As will be argued in the next section, aesthetics in Amerindian worlds seem to be associated with perception, suggesting a discussion about a "sensorial synesthesia" understood as a capacity to "see" beyond ordinary reality. As ritual and shamanism, the aesthetic practice generates complex non-ordinary realities accessible through mediation techniques and specialists that help to bridge the gap between what is visible and invisible (LAGROU, 2013).

\section{Graphism and the quality of "seeing"}

Graphic arts may be found in different surfaces such as human bodies, artifacts, and architectural elements through painting, engraving, or weaving (LAGROU \& VAN VELTHEM, 2018). Though effective in 
establishing differences from other groups, its value rests on signaling continuity with non-human worlds and cosmology rather than displaying the community's internal differences (LAGROU, 2009). As a synthetic perception of multiple realities (VAN VELTHEM, 2010), it links different performative modes that "help to establish guidelines for novices on how to understand otherness in a fractal universe*" (LAGROU \& SEVERI, 2013:15). It has also been described as "a technique of visualizing the perceptual processes of transformation, which allows us to think about how the passages between points of view are produced, how bodies become transparent, how one passes from a line to a face"* (LAGROU, 2009: 90).

In Amerindian contexts, graphic arts are a way of materializing social, moral, and cosmological orders into a visual expression and may be analysed through two different perspectives that intermingle in the final product, which may be a painting, a drawing, a sculpture, or other means by which a visual stimulus is provided. On the one hand, the technical components involve what materials, colours, and shapes are used in the graphic production. On the other, graphic arts relay the meaning of other performative experiences and senses into a "capacity of seeing", usually through dreams, trance states, or through semiotic transformations of oral transmission.

The meaning of graphism may not be exclusively related to the surfaces where they are seen. Gow (1990) explains that Piro designs Yona - are only applied to some surfaces that are close to human action, such as pottery for drinking manioc beer, clothes, or human skin. In order to become "beautiful," patterns must correctly adapt to the surfaces where they are painted, only in that way, by expressing "true" Piro knowledge, they may be regarded as "real" Piro things. On another account, the ornamental graphism present in Wauja's material culture follows the same logic of "supernatural clothes*", they are transformational according to its "compulsive and spontaneous plasticity*" or as "painting made action*", and may be present in different surfaces for different purposes (BARCELOS NETO, 2002).

On addressing ritual artifacts, Hugh-Jones (2009) argues that "breath and intention are attributed to some artifacts placing them in the social praxis of collectivities" and by extension, "thoughts, designs, and intentions are given material form in the objects that the intentions produce" (ibid: 48), while Santos-Granero (2009) talks about "the degree of animacy and agentivity attributed to objects" (ibid: 21 ). Not having bounded and tight subject-object relationships and barriers is essential to understand how dynamic Amerindian worlds are concerning what is alive or not, of what are materials and tools, and what instead may be included in categories of agency. Among the Wayana, for example, the brushes used to paint bodies "know" different graphisms and are used according to the desired objective (VAN VELTHEM, 2013). The kinds of decoration used in painting define who is being painted. While a uniform decoration implies the body decoration of humans, the dotted decorative form reproduces the jaguar and metonymically other animals and the spaces they inhabit. Stripes, instead, represent iconographically the 
rainbow, the physical manifestation of a supernatural serpent as well as other supernatural beings and their power. In their cosmology, all components of the universe have colour. Cited in different mythical narratives, the trilogy of colours white/ red/ black are codes for different physical and social states both of humans and non-humans functioning as a "cosmological identification vector*" (VAN VELTHEM, 2013). Cesarino (2013) has also identified connections between colours used in the drawings and the respective cosmological significance. The drawn tree stumps were consistently coloured according to the respective owner. In addition to the precise location on the paper where the tree stumps were drawn, signaling its "cosmogeography*", these two "classificators*" inform about the sociocosmic segment from where the respective owners are. Among the Mebêngôkre (Kayapó) materials such as genipapo (Genipa americana) and urucu (Bixa orellana) are active substances on the modeling of humans by conferring protection (urucu) against other people's karõ (vital substance), and as a modeling agent (genipapo) by thickening the skin and maintaining one's karõ inside the body (DEMARCHI, 2013).

The effects of visual stimulus are not only directly related to its correspondent empirical origin. Instead, they may be more related to a perception of agency. Due to the immense subjective peril of the environment and the omnipresence of non-humans, Amerindian groups attribute different values to the senses. More than often, the exegesis of an event or situation requires a combination of the senses in order to declare its validity. Either through objects, hallucinogenic trances, dreams, or by a combination of senses, immaterial events and beings are "seen" (FORTIS, 2012: VIVEIROS DE CASTRO, 2006).

For what concerns vision, the Huni Kuin (KEIFFENHEIM, 1999) sustain that it is the most unstable of the senses and must be compensated with a combination of other senses, preferably olfactory and audition, building upon what the author called a "cognitive linkage" and a holistic view of reality. Different capacities of seeing depend on the stimulus and the amount of ordinariness and non-ordinary reality expected to be perceived. The synaesthetic combination of senses, audition, olfaction, and vision correspond to the "unbroken reality of original creation" (ibid: 33 ) in opposition to the fragmented reality allowed by "monomodal" sensory perception. The Huni Kuin use these three modes of "seeing" concomitantly and differentiated only by the social situation and stimulus. Similarly, among the Wauja (BARCELOS NETO, 2001), vision and visual elements are considered along with audition, the fundamental sensorial means to contact non-human worlds. Among the Shipibo-Conibo, the abstract patterns Kené are visual stimulus coded in chants and melodies that are translated into visual patterns materializing experiences in the form of healing, bodily paintings, or drawings (CARNEIRO DA CUNHA, 1999; GOW, 1990). The painted body as a "thinking body"* (CESARINO, 2012) allows Marubo shaman's romeya internal double to acquire knowledge of all languages and cosmic directions, enhancing the importance of the body's holistic empirical recognition. The synaesthetic conversion is paramount to bring to life the 
supernatural beings and engage them in ritual operations in favor of the collectivity (SANTOS-GRANERO, 2009). The making of ritual masks among the Wayana and Miraña involves the "input of nonvisual elements such as movement, sound, and fragrances" (ibid. 18). In Kuna praxis (FORTIS, 2012), the bathing in aromatic plants and the use of olfactory senses to attract entities and befriend them reveals the sensorial pragmatism of Amazonian collectives for relational interaction. Contrarily, the Kisêdgé relate to the visual capacities as extremely dangerous and a nefast experience only acquired when "immoral" acts are practiced. Among this collective, hearing is the most important of the senses to share the social hegemonic norms. Perfect hearing, which stands for the complex of "hearing-understanding-knowing," is incompatible with perfect vision. Seeing, among the Kisêdgé, connects the individual to the natural world, to the world of beings with precise vision, of menacing and asocial things (SEEGER, 1981: 80-91 apud BARCELOS NETO, 2002).

In this sense, due to the extraordinary ontological differences among Amerindian peoples, what is possible to "see" depends on the ontological world and mechanisms of perception associated with the group. Furthermore, "seeing" is a capacity often circumscribed to subjects that acquired knowledge from ancestors, non-human beings, or nonordinary experiences. Dealing with non-humans is dangerous, reason why mediation is considered a difficult political dialogue normally accessible to individuals who obtained specialized training and are capable of communicating and understanding beyond ordinary reality. The kind of relationships that emerge from relational contact must be built and kept, non-humans must be nurtured, asked for help, battled, avoided, or interpreted, and the shaman needs to develop knowledge of the cosmological events and agents, overcome fear of terrible nightmares, of dealing with such powerful entities and eventually of dying.

The condition of invisibility of relational beings is widely justified in Amazonian context (MILLER, 2009) by the mythical origin of humanity where a certain event provided different bodies to different beings eminently through transformation. It explains why the occult human perspective, often associated with the "image" inside the bodies, is hidden from ordinary reality (FORTIS, 2012). Thus visibility does not determine the ontological status of reality and agency, and is not an intrinsic characteristic of an agent, it rather deals with the quality of the observer (MILLER, 2009: 62 apud STOLZE LIMA, 2002).

The ability to see has this ambivalent double function, while specialists are profoundly bound to the non-human worlds and agents, being capable of "seeing" their actions and shapes, aesthetics signal many times a complementary reality to both humans and non-humans, they are to be "seen". Paolo Fortis (2012) draws on Kuna's wooden sculptures to explain connections between art, shamanism, ontology, and kinship. To see beyond the ordinary limits of everyday life is a matter of establishing relationships between invisible beings and humans, more specifically between the shaman and non-human entities. This ability is more common but not exclusive of shamans who are able to "see" the soul beyond the wooden carved figures. According to the author, it is the visual 
capacity of Kuna "seers", nelekana, that enables them to see nuchukana (helper spirits) in their real appearance as people, to converse and learn from them, whereas others are only able to see the carved wooden figure that hosts a primordial soul. Wooden statues, therefore, act as a "boundary to human visual perception" (FORTIS, 2012: 3). As another example, Nixi pae is a Huni Kuin ritual that reveals the hidden reality of the agency of non-humans who have the power to cause pain, illness, and death (LAGROU, 2018). The performance comprises the ingestion of ayahuasca brew and is mediated with the use of songs in a ritual process composed of calling the spirits, taming them, enabling them to "see", and sending away the spirits. Among the Wauja, the yakapá (shamans) use tobacco to develop a differentiated vision allowing access to the supernatural. The use of tobacco keeps auxiliary apapaatai happy, and the yakapá smokes "so light can enter the eyes and allow him to see" (BARCELOS NETO, 2002: 209).

\section{Amerindian drawings}

Drawing as a method for research in Amerindian context has been vaguely used by anthropologists, however, some experiments were conducted from the 1970 s onwards. In Colombia, Reichel-dolmatoff (1973) asked Tukano shamans to draw their travels and dreams after hallucinogenic experiences using Banisteriopsis caapi. Similar attempts were conducted by Vera Coelho back in the 1980s in her work with the Wauja in Brazil (COELHO, 1992). Thomas Gregor's (1977) ethnography includes some watercolor drawings to illustrate certain aspects of social life, maps, and cosmological entities drawn by Mehinacu people. More recently, Pedro de Niemeyer Cesarino (2013), Carlos Fausto (2008), and Aristóteles Barcelos Neto (2002) are examples of current efforts in exploring and systematizing Amerindian drawings as a relevant source of ethnographic data.

According to Barcelos Neto (2002), as in myth, drawings reveal a particular perception of temporality because what is "seen" on paper are replicas of ancient beings which the Wauja consider to have crossed the border separating humanity from animality. Myths are then renovated through ritual and other expressions such as music, dance, featherwork, and graphism. As such, drawings allow for a blurred conception of spacetime settings as they do not need to follow a logical sequence of time or space and serve as an indicator of how humans think about their place in the world and how they perceive relationships with non-human identities (BARCELOS NETO, 2002). Similarly, one other recent study focused on transferring specialized Marubo's shamanistic verbal knowledge from mythic and cosmological narratives into drawings (CESARINO, 2013). Based on a previous experiment conducted by Baer (1994), the author explains how these drawings did not have the same "efficacy" of kene designs also used by the Marubo. Instead, the drawings were included in a category - yochi - that designates photographs, copies, and reproductions (CESARINO, 2013). By the fact that copies and 
representations are understood as endowed with the same characteristics and originated from the same "fabrication" techniques as the original model (LAGROU, 2009), they reveal meaningful connections between bodies, objects, artifacts and images (HUGH-JONES, 2009). While the Marubo responded to Cesarino's appeal by drawing "naturalistic" images of trees and village maps, the knowledge needed to draw relational and mythic scenarios was restricted to shamans - (Barcelos Neto (2002) had a similar experience). The shaman's drawings replicated the "formular sequence"* (CESARINO, 2013) generally present on different kinds of chanted narratives used to describe origin, travel, and final location of spirits, animal doubles, ancestors, the white man, and foreigners. This biographic formula respects what the Marubo consider to be the way to "know" and is only available to specially trained people, who nurtured a relationship with the "doubles" located inside the body and constitute what is known as the "multiple person" and reflex of personhood. The transition of the knowledge made available by "doubles" and spirits in the form of chants is transposed through the use of specific components of the drawing, transversal to the three participant shamans. The composition uses visual metaphors that correspond to the triad of knowledge present in mythical-cosmological narratives and serves for the Marubo as answers to many social events. For example, in death, the double of the eye verõ yochĩ must retrace the steps back to the place where it was born, and the "double" connected to the heart/thinking may retrace the accumulated experiences in life in order to access the ancestor's original places distributed in different parts of the cosmos (CESARINO, 2013). In the examples portrayed by the author, a circle is identified with the origin, and a trace connects it to the final location, which is usually the community's longhouse maloca. The drawings were completed with the inclusion of trees (as a metaphor for tree people) and humanoids (CESARINO, 2013). Some of the drawings relate to Marubo's cosmography, including the origin, home, and trajectories of different spirits and beings, useful to distinguish the location of each "master of animals", and the origin and destination of each type of spirit. They were drawn respecting the groups of Tree people where each comes from, with different body paintings related to the accepted sociocosmic order and kinship relations.

Other kinds of drawings have been emerging from individual sources. Noé Silva Morales's work, Ashaninka ayahuasquero and artist, is considered hybrid due to the coming together of Western figurative techniques, indigenous body painting, and visionary shamanic experiences. This form of art is inseparable from its audience, usually, tourists kin to understand Amazonian cosmovisions and get a closer insight into indigenous knowledge and renowned curative powers (BELAUNDE, 2011). Similar works of Pablo Amaringo (CHARING et al., 2011 ) and other indigenous and mestizo individuals feed the ever more demanding market of shamanic tourism (BELAUNDE, 2011). Drawing has also been used to increase the power of communities in controlling representations and claims of territory and a way to complement governmental maps (SMITH et al., 2017). Previously defined as "counter- 
mapping" (PELUSO, 1995), through participatory mapping, spatial knowledge is ensured for generations as an educational and pedagogical tool (GAVAZZI, 2012). These kinds of drawings are made in collaboration with communities using different kinds of materials, from sand drawing to computer-based software, it has been an important tool used by indigenous peoples, researchers, NGOs, and governmental agencies to address Indigenous territory claims and to empower local communities in self-determination processes.

\section{The ontological drawing}

Drawing is one of the most ancient ways of expression and evokes different values and knowledge according to whose perspective is at stake. It depicts everyday life, dreams or mythic events, and semantic transformations of these and other themes. More importantly, like other Amerindian expressions, it crystallizes worlds along with its intricate relational web while materializing the conspicuous presence of alterity relations and beings.

This article's purpose was to present an overview of drawing as a method in Anthropology, and how in order to be used as a method for research, it must recognize the existence of different ontological environments. There are also considerations to be made to avoid what could be understood as a tentative of binding ontologies in full circled worlds. As previously argued, the art of "making things" for Amerindians has been generally accepted as a personal experience of living. As such, the ontological drawing does not presuppose that an individual experience as an ontological marker could be generalized to the group or a more comprehensive categorization of Amerindian aesthetic experience. It rather looks for clues of the social, moral, and ethical values possible to transmit through personal perception and its expression through drawing. Due to the specific and diversified character of aesthetics for Amerindian peoples, the use of drawing as a method for research must consider the entanglement of agencies and alterity relations that are brought with its production. By identifying the grades of "animacy" (SANTOS-GRANERO, 2009) of the different materials used in drawings, together with the "chimeric" potential of images (LAGROU \& SEVERI, 2013), and by understanding the transformational possibilities of the senses and beings, it may extend possibilities of better expressing some particular traits of Amerindian ontologies through means that have been overlooked and insufficiently explored.

Drawing was defined as a subjective interpretation of reality dependent on personal characteristics such as manual skills, the personality of the creator, and a convention of drawing (SOUKUP, 2014). As seen above, ontological drawings place different agencies and relationships in communication; they are vivid and dynamic agents of transformation that appeal to mythic, cosmic, and moral orders expressed through the visibility of such agents and relationships. As stated by Barcelos Neto (2002), "extra-human drawings are as real as 
those in the oniric, trance and mythic dimensions", and "the image may activate attributes and agencies which transpose ontological frontiers*" (ibid: 46). As such, reality is not represented, it rather "becomes" visible.

Agreeing with the statement that ontology is not a representation (CARRITHERS et al., 2010), ontological drawings can not follow a symbolic perspective. They should, instead, be understood as a gateway into the world of participants, especially if considering the importance given to the "visual" in perceiving agency for Amerindian societies. It is for this reason important to differentiate ontological drawings from other kinds of visual expressions. What can be looked for in ontological drawings are concepts which are evident in social praxis and relate to alterity. As an example described by Fortis (2012), "separation is (...) seen as safety, while proximity and union mean danger". Thus, ontological drawings may reveal these concepts by scrutinizing their composition. In the drawings presented by Carlos Fausto (2008), the "doubles" are inside the human body and may be represented only in that way because it is the "proximity" that is drawn and not exactly the doubles or the human. Similarly, Vilaça (2000) reports that it was possible to understand relations between interethnic contact and shamanism through a drawing. By asking Wari shaman Maxün Hat to draw a Wari man, the author understood the concomitance of Wari and White identities as bodies covering the person's human soul. The drawing expresses how the integration of White's identity is connected with the ontological features of Wari perspective. Maxün Hat drew two juxtaposed layers of clothes (Wari and White), expressing the capacity of being both identities, just like the Wari shaman is capable of being both human and non-human.

As a methodological tool, ontological drawings refer to the researcher's awareness in identifying the capacities of agency of the different materials used in the process of drawing based on collaborative work as a guide into the world of participants as a principle for "controlling equivocation" (VIVEIROS DE CASTRO, 2014). Furthermore, the participation of non-human agents in the revelation and production of knowledge allows drawings to hold continuity between worlds, producing a leap from the interpretation of stable forms on paper as a product, to an immanent perspective of continuity, where the process of drawing describes what kind of relationships are being drawn. No line is indifferent in these kinds of drawings and attention must be made in respect of who is drawing, by means of whom, who or what is being revealed by different compositions of colours, positions, sizes, and patterns, as well as what is dangerous or impossible of drawing. As seen with the examples of contemporary authors, the use of drawing may help identify relational aspects of Amerindians aesthetics and sociability precepts that entangle different worlds and agencies. As a communicative device, ontological drawings may be an example of how to reach a closer insight into Amerindian ontologies through their own spectacles while attempting to bridge incommensurable worlds. 
Espaço Ameríndio

\section{Bibliographic references}

ABU-LUGHOD, Lila. 1991. Writing Against Culture. In: FOX, Richard (Org.). Recapturing Anthropology: Working in the Present. Santa Fe: School of American Research Press, 1991. p. 137-162.

AFONSO, Ana Isabel. New graphics for old stories: Representation of local memories through drawings. In: PINK, Sarah; KÜRTI, László; AFONSO, Ana Isabel (Orgs.). Working Images: Visual Research and Representation in Ethnography. London: Routledge, 2004. p. 63-83.

AGRAWAL, Arun. Indigenous knowledge and the politics of classification. International social science journal, v. 54, n. 173, p. 287-297, Set. 2002. Available at: https://doi.org/10.1111/1468-2451.00382 . accessed in: 28 Apr. 2021.

ANTONA, Laura. Making hidden spaces visible: Using drawing as a method to illuminate new geographies. Area, v. 51, n. 4, p. 697-705, Dez. 2019. Available at: https://doi.org/10.1111/area.12526. Accessed in: 28 Apr. 2021.

BARCELOS NETO, Aristóteles. Tobacco visions: shamanic drawings of the Wauja Indians. Boletim do Museu Paraense Emílio Goeldi. Ciências Humanas, v. 13, n. 3, p. 501-517, Dec. 2018. Available at: http://dx.doi.org/10.1590/1981.81222018000300002 . accessed in: 28 Apr. 2021.

BARCELOS NETO, Aristóteles. A arte dos sonhos: Uma iconografia ameríndia. Lisboa: Museu Nacional de Etnologia/Assírio \& Alvim, 2002.

BARCELOS NETO, Aristóteles. O universo visual dos xamãs wauja (Alto Xingu). Journal de la société des américanistes, n. 87, p. 137-160. 2001. Available at: https://doi.org/10.4000/jsa.1958 . accessed in: 28 Apr. 2021.

BELAUNDE, Luisa Elvira. Movimento e profundidade no kene shipibo-konibo da Amazônia Peruana. In: LAGROU, Els; SEVERI, Carlo (Orgs.). Quimeras em diálogo: grafismo e figuração nas artes indígenas. Rio de Janeiro: 7Letras. 2013. p. 199-222.

BELAUNDE, Luísa Elvira. Diseños materiales e inmateriales: la patrimonialización del kené shipibo-konibo y de la ayahuasca en el Perú!. Mundo amazónico, v. 3, p. 123-146. 2012.

Available

at: https://revistas.unal.edu.co/index.php/imanimundo/article/view/28715 . accessed in: 28 Apr. 2021.

BELAUNDE, Luísa Elvira. Visión de espacios en la pintura shamanica del sheripiare Asháninka Noé Silva Morales. Mundo amazónico, v. 2, p. 365-378. 2011. Available at: https://revistas.unal.edu.co/index.php/imanimundo/article/view/19509 . accessed in: 28 Apr. 2021.

BLASER, Mario. Ontological conflicts and the story of people in spite of Europe: Towards a conversation on political ontology. Current Anthropology, v. 54, n. 5, p. 547568. 2013. Available at: https://doi.org/10.1086/672270 . accessed in: 28 Apr. 2021. 
BLASER, Mario. Political Ontology. Cultural Studies, v. 23, n. 5, p. 873-896. 2009. Available at: https://doi.org/10.1080/09502380903208023 . accessed in: 28 Apr. 2021.

BORDIEU, Pierre. Distinction: A social critique of the Judgement of Taste. Cambridge: Harvard University Press. 1984.

CALVO, Cesar. The three halves of Ino Moxo: teachings of the wizard of the upper Amazon. USA: Inner Traditions International. 1995.

CARNEIRO DA CUNHA, Manuela. "Pontos de vista sobre a floresta amazônica: xamanismo e tradução. Mana, v. 4, n. 1, p. 7-22, Apr. 1998. Available at: https://doi.org/10.1590/S0104-93131998000100001 . accessed in: 28 Apr. 2021.

CARRITHERS, Michael; CANDEA, Matei; SYKES, Karen; HOLBRAAD, Martin; VENKATESAN, Soumhya. Ontology Is Just Another Word for Culture: Motion Tabled at the 2008 Meeting of the Group for Debates in Anthropological Theory, University of Manchester. Critique of Anthropology, v. 30, n. 2, p. 152-200, Jun. 2010. Available at: https://doi.org/10.1177/0308275X09364070 . accessed in 28 Apr. 2021.

CESARINO, Pedro de Niemeyer. Imagens dobráveis: posição e ubiquidade nos xamanismos ameríndios. Bol. Mus. Para. Emílio Goeldi. Ciênc. hum. Belém, v. 14, n. 2, p. 499-512, Aug. 2019. Available at: https://doi.org/10.1590/1981.81222019000200012. accessed in: 28 Apr. 2021

CESARINO, Pedro de Niemeyer. Cartografias do cosmos: conhecimento, iconografia e artes verbais entre os Marubo. Mana, Rio de Janeiro, v. 19, n. 3, p. 437-471, Dez. 2013. Available at: https://doi.org/10.1590/S0104-93132013000300002 . accessed in: 28 Apr. 2021.

CESARINO, Pedro de Niemeyer. A escrita e os corpos desenhados: transformações do conhecimento xamanístico entre os Marubo. Revista de Antropologia, v. 55, n. 1, p. 75 137 2012. Available at: https://doi.org/10.11606/2179-0892.ra.2012.47583 . accessed in: 28 Apr. 2021.

CHARING, Howard; ClOUdsley, Peter; AMARINGO, Pablo. The Ayahuasca visions of Pablo Amaringo. Rochester: Inner Traditions. 2011.

CHILISA, Bagele. Indigenous Research Methodologies. USA: SAGE Publications, Inc. 2012

CLIFFORD, James; MARCUS, George, E. (Orgs.). Writing Culture: The poetics and politics of ethnography. USA: University of California Press. 1986.

COLLET, Celia Leticia. A escrita alfabética e o xamanismo indígena. Muiraquitã: Revista De Letras E Humanidades, v. 2, n. 1, p. 72-92. 2013. Available at: https://doi.org/10.29327/210932.2.1-4 . accessed in 28 Apr. 2021.013.

CECÍLIA DE OLIVEIRA, Rachel. Aporias da pluralidade: como (....) sobre o que ainda não existe. In: DAMIÃO, Carla Milani; BRANDÃO, Caius (Orgs.). Estéticas Indígenas: 
III colóquio de estética FAFIL/UFG. Goiânia: Gráfica UFG. 2019. p. 72-85.

DAMIÃO, Carla Milani; BRANDÃO, Caius. Apresentação. In: DAMIÃO, Carla Milani; BRANDÃO, Caius (Orgs.). Estéticas Indígenas: III colóquio de estética FAFIL/UFG. Goiânia: Gráfica UFG. 2019. p. 8-13.

DE LA CADENA, Marisol. Indigenous cosmopolitics in the Andes: conceptual reflections beyond "Politics". Cultural Anthropology, v. 5, n. 2, p. 334-370, Apr. 2010. Available at http://doi.org/10.1111/j.1548-1360.2010.01061.x . accessed in: 28 Apr. 2021.

DEMARCHI, André. Figurar e desfigurar o corpo: peles, tintas e grafismos entre os Mebêngôkre (Kayapó. In. LAGROU, Els; SEVERI, Carlo (Orgs.). Quimeras em diálogo: grafismo e figuração nas artes indígenas. Rio de Janeiro: 7Letras. 2013. p. 247276.

DESCOLA, Philippe. Beyond Nature and Culture. Chicago: The University of Chicago Press. 2013.

ESCOBAR, Arturo. Designs for the Pluriverse: Radical Interdependence, Autonomy, and the Making of Worlds. Durham and London: Duke University Press. 2018.

ESCOBAR, Arturo. Worlds and knowledges otherwise: The modernity/coloniality research program. Cultural Studies, v. 21, n. 2-3, p. 179-210, Apr. 2007. Available at: https://doi.org/10.1080/09502380601162506 . accessed in: 28 Apr. 2021.

FAUSTO, Carlos. Donos demais: maestria e domínio na Amazônia. Mana, v. 14, n. 2, p. 329-366, Out. 2008. Available at: https://doi.org/10.1590/S0104-93132008000200003 . accessed in: 28 Apr. 2021.

FORTIS, Paolo. Kuna art and shamanism: an ethnographic approach. USA: University of Texas Press. 2012.

GALLOIS, Dominique, T. Donos, detentores e usuários da arte gráfica kusiwa. Revista de Antropologia, v. 55, n. 1, p. 19-49, Dez. 2012. Available at: https://www.revistas.usp.br/ra/article/view/46956 . accessed in: 28 Apr. 2021.

GAVAZZI, Renato Antonio (Org.). Etnomapeamento da Terra Indígena Kampa do Rio Amônia: o mundo visto de cima. Rio Branco: APIWTXA, AMAAIAC, CPI/AC. 2012.

GELL, Alfred. Art and Agency: An anthropological theory. Oxford: Clarendon Press. 1998.

GELL, Alfred. The Technology of Enchantment and the Enchantment of Technology. In: COOTE, Jeremy; SHELTON, Anthony (Orgs.). Anthropology, Art, and Aesthetics. Oxford: Clarendon Press. 1994. p. 40-63.

GOW, Peter. Piro Designs: Painting as Meaningful Action in an Amazonian Lived World. The Journal of the Royal Anthropological Institute, v. 5, n. 2 p. 229-246, Jun. 1999. 
Available at: https://doi.org/10.2307/2660695 . accessed in: 28 Apr. 2021.

GOW, Peter. Could sangama read? The origin of writing among the Piro of Eastern Peru. History and Anthropology, v. 5, n. 1, p. 87-103, Apr. 1990. Available at: http://dx.doi.org/10.1080/02757206.1990.9960809 . accessed in: 28 Apr. 2021.

GOW, Peter. Visual compulsion: design and image in Western Amazonian cultures. Revindi: p. 19-32. 1988.

GRAEBER, David. Radical alterity is just another way of saying "reality": a reply to Eduardo Viveiros de Castro. Hau: Journal of Ethnographic Theory, v. 5, n. 2, p. 1-41. 2015. Available at: https://doi.org/10.14318/hau5.2.003 . accessed in: 28 Apr. 2021.

GREGOR, Thomas. Mehinacu: The drama of daily life in a Brazilian indian village. USA: University of Chicago Press. 1977.

HENARE, Amiria; HOLBRAAD, Martin; WASTELL, Sari (Orgs.). Thinking Through Things: Theorising Artifacts Ethnographically. London. Routledge. 2007.

HOLBRAAD, Martin; PEDERSEN, Morten Axel. The Ontological Turn: An Anthropological Exposition. UK: Cambridge University Press. 2017.

HUGH-JONES, Stephen. The fabricated body: Objects and Ancestors in northwest Amazonia. In: SANTOS-GRANERO, Fernando (Org.). The occult life of things: native amazonian theories of materiality and personhood. USA: The University of Arizona Press. 2009. p. 33-59.

INGOLD, Tim (Org.). Key debates in Anthropology. London: Routledge. 1996.

KEIFENHEIM, Barbara. Concepts of perception, visual practice, and pattern art among the Cashinahua Indians (Peruvian Amazon area). Visual Anthropology, v. 12, n. 1, p. 27-48. 1999. Available at: https://doi.org/10.1080/08949468.1999.9966766 . accessed in: 28 Apr. 2021.

KOHN, Eduardo. Anthropology of Ontologies. Annual Review of Anthropology, v. 44, p. 311-27, Ago. 2015. Available at: https://doi.org/10.1146/annurev-anthro-102214014127 . accessed in: 28 Apr. 2021.

LAGROU, Els; VAN VELTHEM, Lucia Hussak. As artes indígenas: olhares cruzados. Revista Brasileira de Informação Bibliográfica em Ciências Sociais - BIB, v. 87, n. 3, p. 133-156. 2018. Available at: https://www.anpocs.com/index.php/bib-pt/bib87/11596-as-artes-indigenas-olhares-cruzados/file . accessed in: 28 Apr. 2021.

LAGROU, Els. Anaconda-becoming: Huni Kuin image-songs, an Amerindian relational aesthetics. Horizontes Antropológicos, v. 24, n. 51, p. 17-49, Ago. 2018. Available at: https://doi.org/10.1590/s0104-71832018000200002 . accessed in: 28 Apr. 2021.

LAGROU, Els. No caminho da miçanga: arte e alteridade entre os ameríndios. Enfoques - Revista dos Alunos do PPGSA-UFRJ, v. 12, n. 1, p. 18 - 49. 2013. Available at: https://revistas.ufrj.br/index.php/enfoques/article/view/12652 . accessed in: 28 Apr. 
2021.

LAGROU, Els. Arte Indigena no Brasil: agência, alteridade e relação. Belo Horizonte: C Arte. 2009.

LAGROU, Els. A fluidez da forma: arte, alteridade e agência em uma sociedade amazônica (Kaxinawa, Acre). Rio de Janeiro. TopBooks. 2007.

LATOUR, Bruno. Reassembling the Social - An Introduction to Actor-NetworkTheory. UK: Oxford University Press. 2005.

MACK, John. Drawing degree zero: the indigenous encounter with pencil and paper. World Art, v. 2, n. 1, p. 79-103. 2012. Available at: https://doi.org/10.1080/21500894.2012.662172 . accessed in: 28 Apr. 2021.

LAW, John. What's Wrong with the One-World World. Presented at the Center for the Humanities, Wesleyan University, Middletown: Connecticut. 2011. Available at: http://www.heterogeneities.net/publications/Law2011WhatsWrongWithAOneWorldWo rld.pdf . accessed in: 28 Apr. 2021.

LITERAT, Ioana. A pencil for your thoughts: Participatory Drawing as a Visual Research Method with Children and Youth. International Journal of Qualitative Methods, v. 12, n. 1, p. 84-98. 2013. Available at: https://doi.org/10.1177/160940691301200143 . accessed in: 28 Apr. 2021.

MIGNOLO, Walter. Introduction: Coloniality of power and de-colonial thinking. In: MIGNOLO, Walter; ESCOBAR, Arturo (Orgs.). Globalization and the decolonial option. Oxon: Routledge. 2010. p. 1-21.

MILLER, Joana. Things as persons: ornaments and alterity among the Mamaindê (Nambikwara). In: SANTOS-GRANERO, Fernando (Org). The occult life of things: native amazonian theories of materiality and personhood. USA: The University of Arizona Press. 2009. P. 60-80.

MIRZOEFF, Nicholas. The right to look: a counterhistory of visuality. USA: Duke University Press. 2011.

MÜLLER, Regina Polo. As artes indígenas e a arte contemporânea. Textos escolhidos de cultura e arte populares, v. 7, n.1, p. 7-18. 2010. Available at: http://dx.doi.org/10.12957/tecap.2010.12046 . accessed in: 28 Apr. 2021.

OVERING, Joanna. Aesthetics is a cross-cultural category: against the motion. In: INGOLD, Tim (Org.). Key debates in Anthropology. London: Routledge. 1996. p. 201236.

OVERING, Joanna. A estética da produção: O senso de comunidade entre os Cubeo e os Piaroa. Revista de Antropologia, v. 34, p. 7-33. 1991. Available at: https://www.revistas.usp.br/ra/article/view/111249 . accessed in: 28 Apr. 2021.

OVERING, Joanna. The shaman as a maker of worlds: Nelson Goodman in the amazon. 
Espaço Ameríndio

Man, v. 25, n. 4, p. 602-619. 1990. Available at: http://www.jstor.org/stable/2803656 . accessed in: 28 Apr. 2021.

OVERING, Joanna; PASSES, Alan. The Anthropology of love and anger: The Aesthetics of Conviviality in Native Amazonia. London: Routledge. 2000.

PELUSO, Nancy Lee. Whose Woods Are These? Counter-Mapping Forest Territories in Kalimantan, Indonesia. Antipode, v. 27, p. 383-406. 1995. Available at: https://doi.org/10.1111/j.1467-8330.1995.tb00286.x . accessed in: 28 Apr. 2021.

QUIJANO, Aníbal. Coloniality and modernity / rationality. In: MIGNOLO, Walter; ESCOBAR, Arturo (Orgs.). Globalization and the decolonial option. Oxon: Routledge. 2010. p. 22-32.

REICHEL-DOLMATOFF, Gerardo. Rainforest Shamans: essays on the Tukano Indians of the Northwest Amazon. London. Themis Books. 1997.

RIBEIRO, Berta. O Artesão tradicional e seu papel na sociedade contemporânea. Rio de Janeiro. FUNARTE/Instituto Nacional do Folclore. 1983.

RODRIGUES, Maria Luisa. 2019. A experiência do projeto Vídeo nas Aldeias: uma entrevista com Vincent Carelli. In: DAMIÃO, Carla Milani; BRANDÃO, Caius (Orgs.). Estéticas Indígenas: III colóquio de estética FAFIL/UFG. Goiânia: Gráfica UFG. 2019. p. 212-223.

SANTOS, Boaventura de Sousa. Beyond Abyssal Thinking: From Global Lines to Ecologies of Knowledges. Review (Fernand Braudel Center), v. 30, n. 1, p. 47-89. 2007. Available at: https://www.jstor.org/stable/40241677 . accessed in: 28 Apr. 2021.

SANTOS-GRANERO, Fernando. Introduction: Amerindian contructional views of the world. In: SANTOS-GRANERO, Fernando (Org.). The occult life of things: native amazonian theories of materiality and personhood. USA: The University of Arizona Press. 2009. p. 1- 32.

SANTOS-GRANERO, Fernando. From baby slings to feather bibles and from star utensils to jaguar stones: The multiple ways of being a thing in the Yanesha lived world. In: SANTOS-GRANERO, Fernando (Org.). The occult life of things: native amazonian theories of materiality and personhood. USA: The University of Arizona Press. 2009. p. 105-127.

SEEGER, Anthony. Porque cantam os Kĩsêdjê? Uma antropologia musical de um povo da amazônia. São Paulo: Cosac Naify. 2015.

SEEGER, Anthony; DA MATTA, Roberto; VIVEIROS DE CASTRO, Eduardo. A construção da pessoa nas sociedades indígenas brasileiras. Boletim do Museu Nacional, Série Antropologia, v. 32, p. 2-19. 1979.

SMITH, Derek, A.; IBAÑEZ, Alicia; HERRERA, Francisco. The Importance of Context: Assessing the Benefits and Limitations of Participatory Mapping for Empowering Indigenous Communities in the Comarca Ngäbe-Buglé, Panama. Cartographica, v. 52, 
n. 1, p. 49-62. 2017. Available at: https://doi.org/10.3138/cart.52.1.3574 . accessed in: 28 Apr. 2021.

SMITH, Linda Tuhiwai. Decolonizing methodologies. UK: Zed Books. 1999.

SØNDERGAARD, Elisabeth, REVENTLOW, Susanne. Drawing as a Facilitating Approach When Conducting Research Among Children. International Journal of Qualitative Methods, v. 18, p.1-11. 2019. Available at: https://doi.org/10.1177/1609406918822558 . accessed in: 28 Apr. 2021.

SOUKUP, Martin. Photography and drawing in Anthropology. Slovak Ethnology / Slovensky Narodopis, v. 62, n. 4, p. 534-546. 2014.

STRATHERN, Marilyn. The Gender of the Gift: Problems with Women and Problems with Society in Melanesia. Berkeley: University of California Press. 1988.

VAN VELTHEM, Lucia Hussak. Evocar outras realidades: considerações sobre as estéticas indígenas. In: DAMIÃO, Carla Milani; BRANDÃO, Caius (Orgs.). Estéticas Indígenas: III colóquio de estética FAFIL/UFG. Goiânia: Gráfica UFG. 2019. p. 15-42.

VAN VELTHEM, Lucia Hussak. Artes indígenas: notas sobre a lógica dos corpos e dos artefatos. Textos escolhidos de cultura e arte populares, v. 7, n. 1, p. 55-66. 2010. Available at: http://dx.doi.org/10.12957/tecap.2010.12052 . accessed in: 28 Apr. 2021.

VIDAL, Lux (Org). Grafismo indígena: estudos de antropologia estética. São Paulo: Editora da Universidade de São Paulo. 2000.

VILAÇA, Aparecida. O que significa tornar-se outro?: Xamanismo e contato interétnico na Amazónia. Revista Brasileira de Ciências Sociais, v. 15, n. 44, p. 56-72. 2000. Available at: https://doi.org/10.1590/S0102-69092000000300003 . accessed in: 28 Apr. 2021.

VIVEIROS DE CASTRO, Eduardo. Cannibal Metaphysics. Minneapolis: Univocal. 2014.

VIVEIROS DE CASTRO, Eduardo. A floresta de cristal: notas sobre a ontologia dos espíritos amazônicos. Cadernos de campo, v. 14/15, p 319-338. 2006. Available at: https://www.revistas.usp.br/cadernosdecampo/article/view/50120 . accessed in: 28 Apr. 2021.

VIVEIROS DE CASTRO, Eduardo. Perspectival Anthropology and the Method of Controlled Equivocation. Tipití, v. 2, n. 1, p. 3-22. 2004.

VIVEIROS DE CASTRO, Eduardo. Cosmological Deixis and Amerindian Perspectivism. The Journal of the Royal Anthropological Institute, v. 4, n. 3, p. 469488. 1998. Available at: https://doi.org/10.2307/3034157 . accessed in: 28 Apr. 2021.

WAGNER, Roy. The invention of culture. USA: University of Chicago Press. 2016 (1975). 
Recebido em: 03/05/2021* Aprovado em: 09/08/2021 * Publicado em: 30/08/2021 